Tanja Komarac*

Stjepan Bešlić***
JEL klasifikacija: M31, L31

Prethodno priopćenje

https://doi.org/10.32910/ep.72.3.2

\title{
UVID U PERCEPCIJU MUZEJA I MOGUĆNOSTI POBOLJŠANJA USLUGE MUZEJA: PERSPEKTIVA STUDENATA
}

Cilj je istraživanja otkriti kako studenti u Republici Hrvatskoj percipiraju muzeje s obzirom na nepostojanje prethodnih istraživanja. Konkretnije, nastojalo se (1) otkriti kako studenti opisuju muzeje i posjetitelje muzeja, (2) otkriti ulogu muzeja u društvu te (3) prikupiti prijedloge studenata radi poboljšanja iskustva posjeta muzeju. Korištena je kombinirana metodologija kvantitativnog i kvalitativnog istraživanja. Kako bi se dobio uvid u percepcije muzeja, kao instrument istraživanja korišten je anketni upitnik s otvorenim i zatvorenim pitanjima. Istraživanje je provedeno na uzorku od 110 ispitanika (studenata). Otkriveno je kako studenti u Republici Hrvatskoj imaju pozitivnu percepciju muzeja i posjetitelja muzeja. Uloga muzeja u društvu vezana je uz edukaciju te kulturno uzdizanje, dok je posebnost muzeja u usporedbi s drugim institucijama u tome što nude specifična znanja $i$ vještine te izlažu autentične predmete. Kod prijedloga za poboljšanje iskustva posjete muzeju, interaktivnost i prilagodba usluga muzeja mladima, najčešće su isticana područja poboljšanja ponude muzeja. Ograničenja istraživanja vezana su uz vrstu i veličinu uzorka, namjerni prigodni uzorak od 110 studenata jednog zagrebačkog fakulteta. Ovo je prvi rad koji, koristeći kombiniranu

${ }^{*}$ T. Komarac, dr.sc., poslijedoktorand, Sveučilište u Zagrebu, Ekonomski fakultet, Katedra za marketing (e-mail: tkomarac@net.efzg.hr)

** S. Bešlić, mag. oec., Alumni Sveučilišta u Zagrebu, Ekonomski fakultet (e-mail: stipe. beslic@gmail.com). Rad je primljen u uredništvo 30.12.2019. godine, a prihvaćen je za objavu 21.04.2020. godine. 
metodologiju istraživanja, daje uvid u to kako studenti u Republici Hrvatskoj doživljavaju muzeje.

Ključne riječi: percepcija studenata, muzeji, Republika Hrvatska, kombinirana metodologija

\section{UVOD}

Unatoč važnoj ulozi muzeja u društvu, oni su suočeni s problemom privlačenja mladih i njihovom popularnošću među mladima. Navedeno potvrđuju i statistički podaci Europske unije o posjećenosti muzeja. Oni pokazuju da $40 \%$ mladih u dobi od 15 do 24 godine i $44 \%$ onih u dobi od 25 do 39 godine nije posjetilo ni jedan muzej ili galeriju u godini dana (European Commission, Special Barometer Report, 2017.). Problem privlačenja mladih i popularnosti muzeja potaknut je promjenama u njihovom životnom stilu u odnosu na prijašnje generacije, razvojem tehnologije i rastom ponude zabavnih sadržaja (Hughes i Moscardo, 2017.). Stoga postoji (opravdana) zabrinutost kako privući današnje generacije mladih u muzeje te kako oni mogu postati mjesta za zabavu i društvenu interakciju među mladima. Prvi korak u prilagodbi muzeja današnjim potrebama mladih jest otkrivanje njihovih percepcija muzeja (Caldwell i Coshall, 2002.) kako bi se otkrio prostor za privlačenje mladih te potencijalno poboljšanje iskustva posjeta muzejima.

Stoga je cilj rada otkriti kako mladi percipiraju muzeje, i to kroz percepcije posjeta muzeja u djetinjstvu, percepcije muzeja danas i osoba koje posjećuju muzeje. Nadalje, nastoji se otkriti po čemu su muzeji jedinstveni te koja je njihova uloga u društvu, a time i u životu mladih. Posljednje, otkrivaju se načini poboljšanja ponude muzeja kako bi oni bili privlačniji mladima.

Rad je podijeljen u sedam cjelina. Nakon uvoda, teorijski okvir rada prikazuje dosadašnja istraživanja o percepciji mladih u području kulture i umjetnosti s naglaskom na muzeje. Nakon toga prikazan je metodološki pristup istraživanju, rezultati, diskusija, ograničenja te zaključak na kraju rada.

\section{TEORIJSKI OKVIR}

Percepcija je bitan osobni čimbenik ponašanja potrošača. Percepcija se definira kao ,proces kojim pojedinac prima stimulanse i daje im smisao na osnovi prethodnog učenja, pamćenja, očekivanja, fantazija, uvjerenje i svoje ličnosti““ 
(Bennet i Kassarjain, 2005 u Kesić, 2006, str. 11). Percepcija ne ovisi samo o fizičkim poticajima nego i o onima koji su vezani za okolinu pojedinca, kao i za njegovo unutarnje stanje. Percepcija varira od pojedinca do pojedinca koji se nalaze u istim situacijama, a svaka osoba reagira drukčije (Kotler i Keller, 2008). Upravo stoga su ova istraživanja izrazito važna i prijeko potrebna.

Marketinški stručnjaci nastoje utjecati na percepciju o određenom proizvodu/ usluzi tako da kreiraju imidž (marke) proizvoda/usluge koji je u skladu s vrijednostima proizvoda/usluge (Assael, 2004). U području kulture i umjetnosti marketinški stručnjaci imaju izazovniji zadatak jer su proizvodi/usluge heterogeni i kompleksni (d'Astous, Voss, Colbert, Carù, Caldwell i Courvoisier, 2008). Percepcija mladih potrošača u području kulture i umjetnosti razlikovat će se ovisno o vrsti proizvoda/ usluga (primjerice, percepcija posjeta koncertima, galerijama, muzejima i sl.).

U kontekstu glazbe, dosadašnja su istraživanja dokazala veliku ulogu glazbe u životima mladih (Rentfrow, McDonald i Oldmeadow, 2009; Manchaiah, Zhao, Wildén, Auzenne, Beukes, Tomé, Mahadeva, Krishna, Germundsson, 2017). Glazba za mlade predstavlja način izražavanja vlastite osobnosti i identiteta (Rentfrow i sur., 2009). U istraživanju mladih o glazbi iz pet različitih zemalja (Indije, Irana, Portugala, Ujedinjenog Kraljevstva i SAD-a) Manchaiah i sur. (2017) otkrili su kako je glazba vezana uz pozitivne emocije, radost, sreću, pjevanje, plesanje i zabavu. No postoje određene razlike u percepcijama mladih između različitih vrsta glazbe (klasične glazbe, jazza, rock-glazbe, pop-glazbe, elektronske glazbe i rap glazbe) (Rentfrow i sur., 2009).

Istraživanje na Novom Zelandu kako mladi percipiraju umjetničke galerije otkrilo je da imaju zdravorazumske, ali podijeljene percepcije te da se u galerijama ne osjećaju „kao kod kuće“ (Mason i McCarthy, 2006). Isto tako, percepcija o posjetiteljima umjetničkih galerija vezana je uz osobe koje vole umjetnost, otmjene su i sofisticirane. Autori ističu kako ovakve institucije trebaju biti više inkluzivne te se prilagoditi potrebama mladih kako bi se osjećali dobrodošlo.

Sve je više istraživanja kako mladi doživljavaju muzeje. Rezultati istraživanja pokazuju da oni imaju negativnu percepciju (Drotner, Vestergaard Knudsen i Hviid-Mortenesen, 2017) što dovodi do njihove nezainteresiranosti za posjet muzejima (Gofman, Moskowitz i Mets, 2011). Mladi od muzeja očekuju zabavu, društvenu interakciju (Hughes i Moscardo, 2019), interaktivnost s muzejom i izloženim predmetima (Farrell i Medvedeva, 2010.). Dio muzeja to je već prepoznao i uspješno nudi zabavu korištenjem različitih interaktivnih tehnologija koje pomažu ostvarenju edukativnih ciljeva kao i ciljeva posjeta samih posjetitelja (Hughes i Moscardo, 2017).

Negativna percepcija muzeja vezana je uz njihovu naglašenu tradicionalnu orijentaciju na očuvanje baštine, a ne na posjetitelje, njihove želje i potrebe. 
Dodatno, marketinški stručnjaci u muzejima često ne mogu utjecati na to što će muzej nuditi posjetiteljima (Colbert, 2014). Istraživanje Drotnera i sur. (2017) otkrilo je podijeljene percepcije mladih o muzejima u Danskoj. Otkrili su kako jedni imaju negativnu (dosada), a drugi pozitivnu percepciju muzeja (mjesta opuštanja, zabave i uzbudljivih iskustava). Dio razloga teži u disonanci između onoga što muzej i nude i što mladi žele od muzeja. U manjem broju istraživanja muzeji su percipirani pozitivno, kao mjesta edukativne zabave (Hanquinet i Savage, 2012), mjesta zabave i uzbudljivih iskustava (Drotner i sur., 2017).

Očito je da posljednjih deset godina mladi imaju sve veća očekivanja od muzeja. Tako očekuju dobivanje sveobuhvatnih, interaktivnih, relevantnih, fleksibilnih, novih i autentičnih iskustava (Farrell i Medvedeva, 2010). Hughes i Moscardo (2019) istraživali su kako muzeje učiniti privlačnijima mladima prikupljajući njihove prijedloge. Tako mladi žele više interaktivnih izložbi uz korištenje modernih tehnologija (54\%), više sadržaja prilagođenog mladima (39\%), posebne tematske događaje koji nude mogućnost socijalizacije (20\%), modernije fizičko uređenje muzeja (15\%), bolje oglašavanje na društvenim mrežama (14\%) te posebne ponude, popuste, prilike i natjecanja za mlade (12\%).

Razlike u percepcijama mladih o muzejima vezane su i uz dob. Tako su Caldwell i Coshall (2002) ustanovili da postoje vidljive razlike u mentalnim strukturama mladih u dobi ispod i iznad 35 godina, a koje se odnose na njihovu povezanost s muzejima. Otkriveno je da mladi (do 35 godina) pri formiranju percepcije muzeja koriste puno više kriterija, poput individualne motivacije, očekivanja, zadovoljstva i njihova utjecaja na ponašanje drugih posjetitelja (Thyne, 2001). Nadalje, mladi s nižim prihodima od muzeja očekuju više kulturne zabave (Sheng i Chen, 2012).

Isto tako, na percepciju mladih utjecaj može imati i inkluzija (engl. inclusion) mladih kao posjetitelja muzeja u razvoj usluge muzeja koja će bit prilagođena njihovim potrebama. Inkluzija podrazumijeva uključivanje različitih ljudi u muzejsku zajednicu (Salgado, 2009) pa za muzeje predstavlja ,ideal“, nastojanje da osiguraju i povećaju javni pristup, tradicionalno manje zastupljenih skupina (Kinsley, 2016). Inkluzija mladih i prilagodba ponude muzeja mladima jedan je od najvećih izazova (Tzibazi, 2013). Tako se muzeji odmiču od starog imidža obrazovnih ustanova namijenjenih homogenoj skupini posjetitelja. Mladi odbijaju biti pasivni promatrači muzeja koji će usvojiti ,,mudrosti“ muzeja. Oni žele biti aktivno uključeni kako bi mogli izraziti svoje znanje i mišljenje (Tzibazi, 2013). Muzeji im se stoga trebaju prilagoditi kako ne bi izgubili važnost u životima mladih.

U praksi sve više muzeja nastoji uključiti mlade u oblikovanje svoje ponude kako bi se promijenio negativan imidž muzeja i utjecalo na percepciju mladih o muzejima. Tako je, primjerice, National Museum of Scotland (Edinburgh, UK) 
na temelju provedenih istraživanja na mladima ponudio brojne dodatne usluge $u$ muzeju u obliku organiziranih večernjih događaja namijenjenih mladima. Neke od dodatnih usluga su igranja videoigara, disko, stručni razgovori, prostori za socijalizaciju uz hranu i piće (Barron i Leask, 2017). Museum of London (London, UK) upotrijebio je drugačiji pristup u privlačenju mladih ljudi. Oformili su konzultantsku skupinu The Junction Panel koja se sastoji od mladih koji surađuje s muzejom u organizaciji izložbi, projekata i događaja namijenjenih mladima. Na taj način muzej je ponudio programe koji su kreirani uz pomoć mladih te su privikli brojne mlade posjetitelje (Museum of London, 2019.). Slično tome, Muzej suvremene umjetnosti (Zagreb, Hrvatska) u okviru projekta Translocal: Museum as Toolbox istražio je kako mladi zamišljaju Muzej suvremene umjetnosti, kako je on povezan s njihovom svakodnevnicom, koje su nove stvari koje se mogu iskušati te kako muzeji mogu postati interaktivniji (Museum as Toolbox, 2019). Rezultati istraživanja pokazali su kako mladi žele mogućnosti komunikacije s umjetnicima, vođenje podcasta, puštanje filmova, korištenje različitih medijskih platformi, upoznavanje novih ljudi, audiovodiče, niže cijene ulaznica, besplatan ulaz studentima i slično.

\section{METODOLOŠKI OKVIR}

\subsection{Ciljevi istraživanja $i$ istraživačka pitanja}

Temeljni cilj istraživanja bio je otkriti kako studenti u Republici Hrvatskoj percipiraju muzeje. Konkretnije, navedeni se cilj nastojao ostvariti odgovorima na sljedeća istraživačka pitanja:

- Kako studenti opisuju muzeje i osobe koje posjećuju muzeje?

- Kakva je uloga muzeja u društvu?

- Kako muzeji mogu unaprijedili ponudu da bi pružali bolje iskustvo posjeta?

\subsection{Metodologija istraživanja}

U radu je korištena kombinirana metodologija istraživanja (engl. mix methods) pa su prikupljeni i analizirani kvalitativni i kvantitativni podaci prikupljeni u istom istraživanju (Tashakkori i Creswell, 2007.; Creswell, 2009.). U tu svrhu 
korišten je polustrukturirani anketni upitnik koji se sastojao od šest pitanja otvorenoga tipa na koja su ispitanici u nekoliko riječi ili rečenica odgovarali o percepciji muzeja. Dodatno, kvantitativni podaci su prikupljeni kroz 16 pitanja (tvrdnji) preuzetih i prilagođenih od Hughesa i Moscardoa (2019.) (prilagođeno od Masona i McCarthyja, (2006.) te Shenga i Chena, (2012.)). Ispitanici su razinu slaganja/ neslaganja s predloženim tvrdnjama ocjenjivali korištenjem Likertove ljestvice (od 1 do 5). Posebno su analizirani kvalitativni i kvantitativni odgovori. Dio kvalitativnih podataka o asocijacijama izražen je kvalitativno i kvantitativno u situacijama kada je to bilo moguće.

Istraživanje je provedeno u svibnju i lipnju 2019. godine na Ekonomskom fakultetu u Zagrebu. U njemu su sudjelovali studenti 2. godine Sveučilišnog integriranog preddiplomskog i diplomskog studija Poslovne ekonomije (redovni studenti i izvanredni studenti koji rade uz studij). Ispitanici su samostalno ispunjavali (papirnati) anketni upitnik, čime im je zajamčena anonimnost u davanju odgovora te kako bi se izbjegli društveno poželjni odgovori. Ispitanicima je u prosjeku bilo potrebno deset minuta za ispunjavanje anketnoga upitnika.

Uzorak istraživanja bio je namjerni prigodni uzorak od 110 ispitanika, studenata od 19 do 35 godina koji su u potpunosti ispunili upitnik. Upravo zbog toga što percepcije mladih o muzejima ovise o dobi pa mladi do 35 godina mogu imati drugačiju percepciju muzeja, određena je dobna granica do 35 godina za odabir ispitanika u uzorak (Caldwell i Coshall, 2002). Od 110 ispitanika, 70,9\% bile su žene, a 29,1\% muškarci. S obzirom na dobnu strukturu ispitanika, najviše je ispitanika bilo unutar dobne skupine od 18 do 20 godina, njih 44,5\%, zatim od 21 do 23 godine $40 \%$, od 24 do 26 godina $13,6 \%$ te više od 27 godina svega $1,9 \%$. Prikupljeni su podaci i o završenom stupnju obrazovanja. Najviše je ispitanika sa završenom srednjom školom, njih 93,6\%, zatim 3,6\% onih koji su završili višu školu, a 2,8\% sa završenim fakultetom. Ispitanici su se izjasnili i o ukupnim mjesečnim prihodima svojega kućanstva. Najviše je onih koji na to pitanje nisu htjeli dati odgovor (37,3\%). Tako 18,2\% ispitanika ima mjesečni prihod kućanstva veći od $15001 \mathrm{kn}$, zatim, 15,4\% su onih mjesečnim prihodima kućanstva od 10001 kn do $15000 \mathrm{kn}$. Zatim je 10,9\% ispitanika s mjesečnim prihodima od 7501 do 10000 kn, a svega 7,3\% s prihodima kućanstva do $2500 \mathrm{kn}$ te isto toliko od 2501 do 5000 kn. Najmanje ispitanika s ukupnim mjesečnim prihodima kućanstva od 5001 do $7500 \mathrm{kn}$, a njihov udio u ukupnom broju ispitanika iznosi 3,6\%. Detaljniji podaci o uzorku prikazani su u tablici 1. 
Tablica 1 .

PODACI O UZORKU

\begin{tabular}{|c|c|c|c|}
\hline Varijabla & Kategorija & Postotak & $\begin{array}{c}\text { Broj ispitanika } \\
\text { (n=110) }\end{array}$ \\
\hline \multirow{2}{*}{ spol } & muški & $29,1 \%$ & 32 \\
& ženski & $70,9 \%$ & 78 \\
\hline \multirow{3}{*}{ dob } & $18-20$ & $44,5 \%$ & 49 \\
& $21-23$ & $40 \%$ & 44 \\
& $24-26$ & $13,6 \%$ & 15 \\
& 27 i više & $1,9 \%$ & 2 \\
\hline \multirow{2}{*}{ završeni stupanj } & srednja škola & $93,6 \%$ & 103 \\
obrazovanja & viša škola & $3,6 \%$ & 4 \\
& fakultet & $2,8 \%$ & 3 \\
\hline \multirow{3}{*}{ ukupni mjesečni } & do 2500 kn & $7,3 \%$ & 8 \\
prihodi kućanstva & od 2501 do 5000 kn 5001 do 7500 kn & $7,3 \%$ & 8 \\
& od 7501 do 10000 kn & $3,6 \%$ & 4 \\
& od 10001 do $15000 \mathrm{kn}$ & $10,9 \%$ & 12 \\
& više od 15000 kn & $18,4 \%$ & 17 \\
& ne želi odgovoriti & $37,3 \%$ & 20 \\
\hline
\end{tabular}

Izvor: Istraživanje

\section{REZULTATI ISTRAŽIVANJA I INTERPRETACIJA REZULTATA}

Istraživanjem je otkriveno kako nešto više od polovice studenata rijetko posjećuje muzeje, i to jednom u nekoliko godina $(52,7 \%)$, dok nešto manje od polovice posjećuje ih jednom do dva puta godišnje (40\%), odnosno njih 7,3\% više od 3 puta godišnje. Dio razloga leži i u zainteresiranosti ispitanika za posjet muzeju. Tako je otkriveno da su ispitanici u prosjeku indiferentni prema posjetama muzejima, točnije nisu za njih ni zainteresirani ni nezainteresirani. Ovaj rezultat je i djelomično očekivan ako se uzme u obzir da oko polovine ispitanika rijetko posjećuje muzeje (jednom u nekoliko godina), a oko polovine često (jednom ili više puta godišnje). Dodatno, nešto su drugačiji odgovori ispitanika o zainteresiranosti za posjete muzejima dok su na putovanju, gdje je otkrivena veća zainteresiranost dok su na putovanjima u odnosu na posjete općenito, što predstavlja zanimljiv nalaz istraživanja.

Nadalje, otkriveno je kako je za $30 \%$ ispitanika cijena ulaznice muzeja važna, za nešto manje ispitanika, $28,2 \%$, malo važna, dok za $25,4 \%$ nije ni važna ni 
nevažna. Samo 8,2\% ispitanika cijenu ulaznice ocijenilo kao izrazito važnu i isto toliko ih je ocijenilo kao izrazito nevažnu. To dovodi do zaključka da su podijeljena mišljenja ispitanika o važnosti cijena ulaznica muzeja.

Kako polazna točka u odgovorima na postavljena istraživačka pitanja pokušalo se saznati kakva je percepcija ispitanika o posjetima muzejima u djetinjstvu, bilo s obitelji, prijateljima, kao dio školskog programa ili s nekom drugom grupom. Grafikon 1 prikazuje najčešće pozitivne asocijacije vezane uz posjet muzeju u djetinjstvu (ukupno 81). To su asocijacije koje se odnose na sadržaj muzeja koji ispitanici opisuju kao zanimljiv, interesantan, edukativan, pun novih informacija, poučan i sl.

\section{Grafikon 1.}

\section{NAJČEŠĆE POZITIVNE ASOCIJACIJE VEZANE UZ POSJET MUZEJU U DJETINJSTVU}

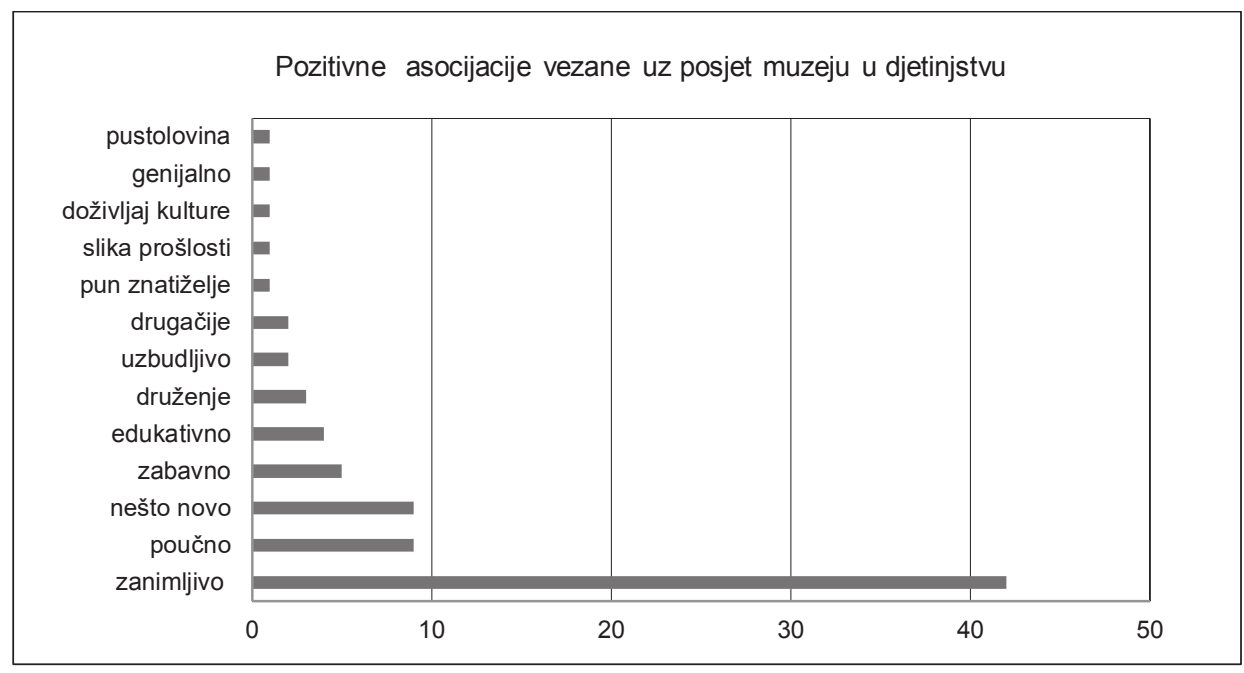

$\mathrm{N}=89$

Napomena - učestalost pojavljivanja asocijacija u odgovorima ispitanika (u apsolutnim iznosima)

Izvor: istraživanje autora

Neutralnih je asocijacija manje u odnosu na pozitivne (svega 14). One se odnose na individualnost doživljaja ispitanika te na dobra i loša iskustva koja ovise o muzeju. Općenito su neutralne asocijacije prema posjetu muzeju u djetinjstvu rezultat dobrih iskustava u jednom muzeju i loših iskustava u nekom drugom. Neutralna asocijacija koja se također javlja kod više ispitanika odnosi se na činjenicu da nije zapamćen posjet muzeju u djetinjstvu. 
Ispitanici su također istaknuli negativne asocijacija vezane uz posjete muzeju u djetinjstvu (ukupno 23). Tako su neke od najčešćih da je posjet muzeju u djetinjstvu bio dosadan, naporan, zamoran, nezanimljiv i sl. Neki ispitanici negativne asocijacije vežu i uz kustose u muzejima za koje smatraju da im nisu bili zanimljivi. Zanimljivo je da je dio ispitanika, koji su imali negativne asocijacije na posjet muzeju u djetinjstvu, istaknuo da su se te asocijacije pretvorile u pozitivne (s godinama).

Vezano uz istraživačko pitanje kako mladi opisuju muzeje i osobe koje ih posjećuju, prikupljeni kvalitativni podaci pokazali su kako dominiraju pozitivne asocijacije na muzeje (ukupno 179). Najčešće pozitivne asocijacije koje se spominju jesu da su zanimljivi, poučni, informativni, mirni i edukativni (grafikon 2).

\section{Grafikon 2.}

\section{POZITIVNE ASOCIJACIJE KOJIMA SU ISPITANICI OPISALI MUZEJE U 3 RIJEČI}

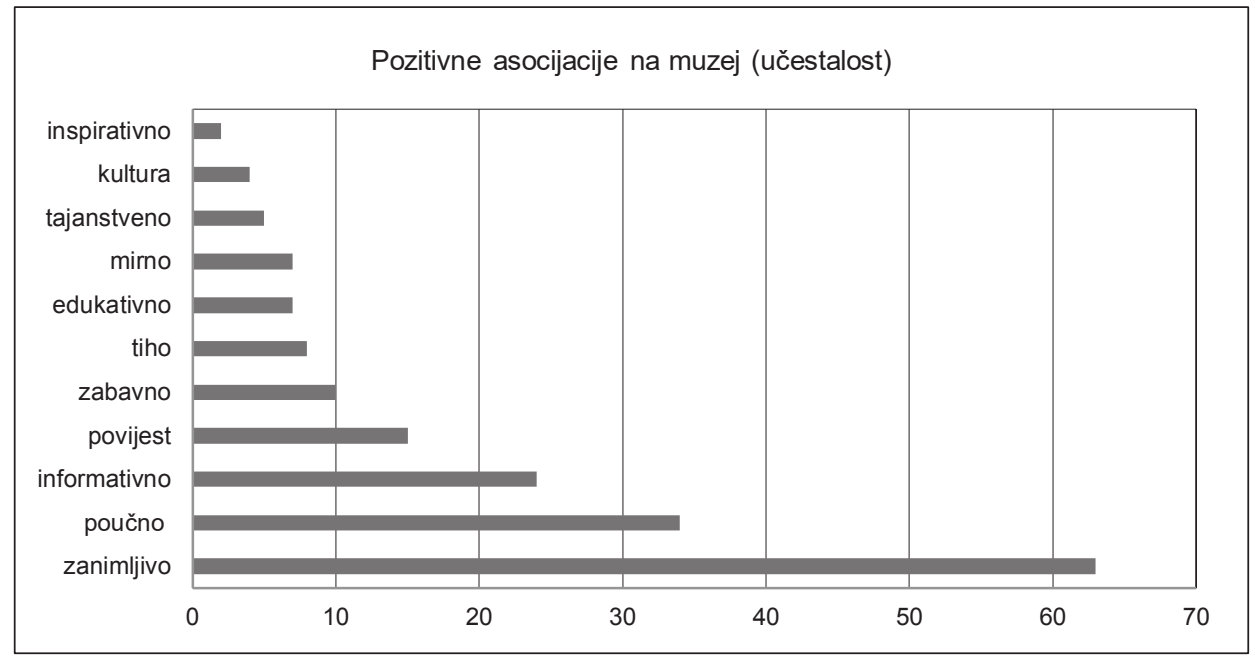

$\mathrm{N}=107$

Napomena - učestalost pojavljivanja asocijacija u odgovorima ispitanika (u apsolutnim iznosima) Izvor: istraživanje autora

Negativnih je asocijacija o muzejima bilo relativno malo (ukupno 19). U najvećoj mjeri one su se odnosile na atmosferu. Tako su ispitanici muzeje opisali kao hladne, mračne i sumorne. Osim toga, iskustvo posjeta muzeju opisuju kao dosadno i nezanimljivo, a neki čak smatraju zastrašujućima.

Ovi rezultati upućuju na postojanje pretežno pozitivne percepcije o muzejima. Za dobivanje dodatnog uvida, korištena su pitanja kojima su željeli prikupiti 
T. KOMARAC, S. BEŠLIĆ: Uvid u percepciju muzeja i mogućnosti poboljšanja usluge muzeja: perspektiva studenata EKONOMSKI PREGLED, 72 (3) 358-376 (2021)

kvantitativni odgovori vezani uz percepciju muzeja. Tako ih ispitanici percipiraju kao mjesta koja pružaju informacije i kojima se može vjerovati, kao mjesta gdje se mogu naći odgovori na određena pitanja (tablica 2). Navedene su asocijacije pozitivne, no više su činjenične jer su vezane uz tradicionalnu ulogu muzeja (mjesta edukacije i kulture), a ne pružanje nezaboravnih iskustava što je trend u muzejskom sektoru.

S druge strane, ispitanici se ne slažu da su muzeji mjesta za zabavu i socijalizaciju kroz razgovore i zajedničke aktivnosti. Isto tako, muzeji ne pokrivaju teme koje ih interesiraju, što upućuje na nedostatak ponude muzeja usmjerenih mladima ili nedovoljnu komunikaciju takvih sadržaja prema toj skupini.

Tablica 2 .

SLAGANJE/NESLAGANJE ISPITANIKA VEZANO UZ 16 OPISA MUZEJA

\begin{tabular}{|l|c|c|}
\hline \multicolumn{1}{|c|}{ Tvrdnje (pitanja) } & $\begin{array}{c}\text { Srednja } \\
\text { vrijednost }\end{array}$ & $\begin{array}{c}\text { Standardna } \\
\text { devijacija }\end{array}$ \\
\hline Muzeji su mjesta gdje se može učiti od ,strastvenih“ ljudi. & 3,5 & 1,01 \\
\hline Muzeji su mjesta gdje se može fotografirati. & 3,16 & 1,18 \\
\hline Muzeji su mjesta gdje se osjećam ugodno i dobrodošlo. & 3,87 & 0,73 \\
\hline Muzeji su mjesta s previše informacija. & 2,86 & 1,14 \\
\hline Muzeji su mjesta koja predstavljaju stavove onih koji su ih dizajnirali. & 3,27 & 1,04 \\
\hline Muzeji su mjesta za zabavu s prijateljima. & 2,83 & 0,97 \\
\hline Muzeji su mjesta za razgovore i zajedničke aktivnosti. & 2,8 & 1,11 \\
\hline Muzeji su mjesta za pričanje zanimljivih priča. & 3,83 & 1,01 \\
\hline Muzeji su mjesta koja pružaju iskustva s kojima se mogu poistovjetiti. & 3,26 & 0,98 \\
\hline Muzeji su mjesta koja rijetko pokrivaju teme koje me zanimaju. & 2,56 & 0,97 \\
\hline Muzeji su mjesta koja pružaju informacije kojima se može vjerovati. & 4,11 & 0,83 \\
\hline $\begin{array}{l}\text { Muzeji su mjesta koja su zastrašujuća ljudima koji ih prvi put } \\
\text { posjećuju. }\end{array}$ & 1,97 & 0,88 \\
\hline $\begin{array}{l}\text { Muzeji su mjesta gdje se mogu vidjeti stvari iz drugih mjesta i } \\
\text { vremena. }\end{array}$ & 4,68 & 0,56 \\
\hline Muzeji su mjesta za razmišljanje u tišini. & 3,83 & 0,85 \\
\hline $\begin{array}{l}\text { Muzeji su mjesta koja me potiču na razmišljanje o temama o kojima } \\
\text { inače ne bih razmišljao/la. }\end{array}$ & 3,87 & 1,04 \\
\hline Muzeji su mjesta gdje se mogu pronaći odgovori na određena pitanja. & 4 & 0,87 \\
\hline
\end{tabular}

$\mathrm{N}=110$

Izvor: istraživanje autora 
Nadalje, ispitanici su opisivali osobu koja posjećuje muzeje navodeći zapažanja o njoj, i to putem 129 pozitivnih asocijacija, a njima se došlo do zaključka da osobu koja posjećuje muzeje smatraju pametnom, znatiželjnom, ambicioznom, obrazovanom i kulturnom. Općenito je opisuju kao osobu koja je stalno željna nekih novih znanja i informacija te je spremna kontinuirano raditi na sebi. Ispitanici, isto tako, povezuju visok stupanj obrazovanja s osobama koje posjećuju muzeje te ih opisuju kao kreativne, pustolovne i željne novih iskustava (grafikon 3).

\section{Grafikon 3.}

\section{POZITIVNE ASOCIJACIJE KOJIMA SU ISPITANICI OPISALI POSJETITELJA MUZEJA U 3 RIJEČI}

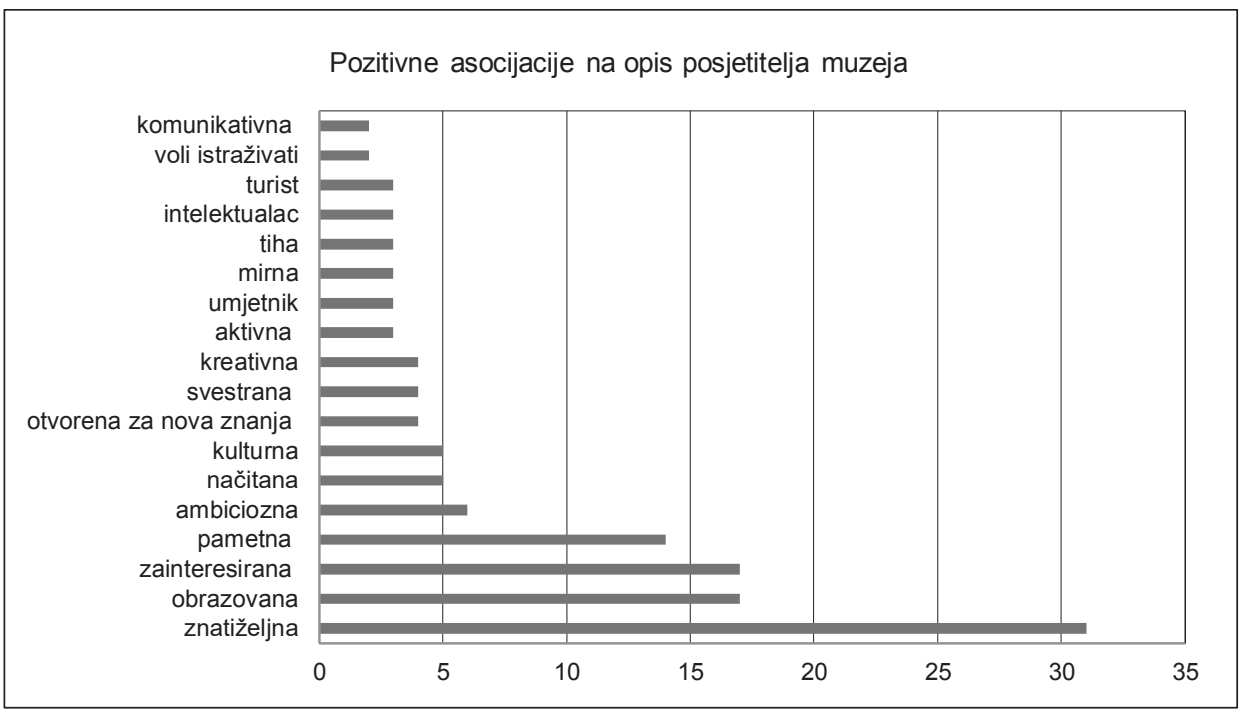

$\mathrm{N}=101$

Napomena - učestalost pojavljivanja asocijacija u odgovorima ispitanika (u apsolutnim iznosima) Izvor: istraživanje autora

Može se zaključiti da je broj negativnih asocijacija ispitanika izrazito nizak (svega 9) te da je percepcija mladih o osobama koje posjećuju muzeje izrazito pozitivna.

Kako bi se odgovorilo na drugo istraživačko pitanje kakva je uloga muzeja u društvu, od ispitanike se tražilo da ukratko opišu svoje viđenje uloga muzeja u društvu. Otkriveno je kako ispitanici smatraju da muzeji imaju pozitivnu ulogu 
u društvu. Muzeji nude edukaciju i dodatno obrazovanje o određenim temama, o prošlim vremenima, povijesnim događajima, osobama i predmetima. Muzeji potiču interes i znatiželju o daljnjem istraživanju navedenih tema i područja. Dodatno, muzeji sudjeluju u kulturnom uzdizanju pojedinca, preko upoznavanja pojedinca s naslijeđem i bogatstvom naroda, svoje, ali i drugih kultura. Osim toga, ispitanici smatraju da je uloga muzeja potaknuti ljude na razmišljanje o nekim nesvakidašnjim temama, odnosno o onima o kojima inače ne bi razmišljali. Zaključno, ističu zabavu i druženje kao jednu od uloga muzeja u društvu.

Od ispitanika se tražilo i mišljenje po čemu su muzeji jedinstveni, odnosno što se može pronaći u muzejima, a da se ne može pronaći nigdje drugdje. Oni su ponudili zanimljive odgovore. Najveći dio odgovora odnosio se na informacije koje se mogu dobiti samo u muzeju, a odnose se na povijesne događaje, predmete i osobe, odnosno specifično znanje koje je povezano s izloženim povijesnim i autentičnim predmetima. Osim toga, u svojim su odgovorima naglašavali provjerenost i točnost informacija koje nude muzeji. Dodatno, naveli su jedinstvene suvenire, odnosno specifične predmete koji se ne mogu kupiti nigdje drugdje. Grafikon 4 prikazuje posebnosti muzeja po mišljenjima ispitanika.

\section{Grafikon 4.}

\section{POSEBNOST MUZEJA PO MIŠLJENJIMA ISPITANIKA}

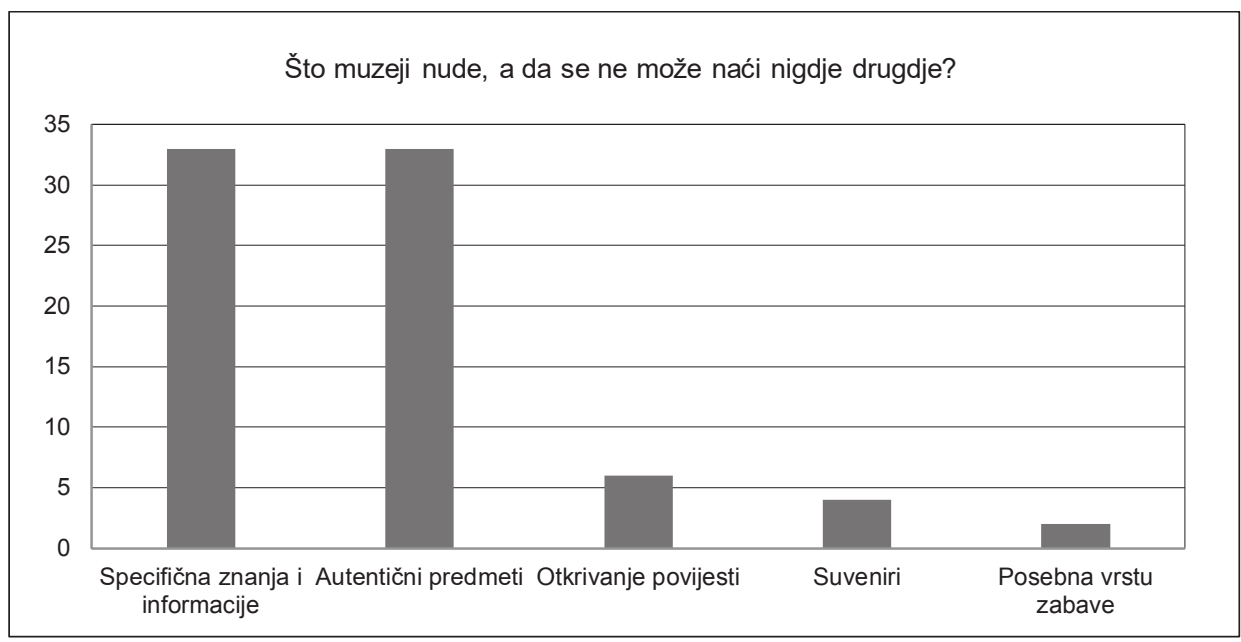

$\mathrm{N}=93$

Napomena: učestalost pojavljivanja asocijacija u odgovorima ispitanika (apsolutne vrijednosti)

Izvor: istraživanje autora 
Na posljednje istraživačko pitanje kako bi unaprijedili ponudu muzeja u svrhu pružanja boljeg iskustva posjete, ispitanici su ponudili brojne prijedloge. Njihovi su prijedlozi grupirani u sedam tematskih grupa koji se odnose na: 1) više interaktivne komunikacije s mladima (na društvenim mrežama i u muzeju kroz igre i zadatke te radionice), 2) više sadržaja prilagođenog mladima (atraktivnije izložbe koje su u skladu s interesima i životom mladih), 3) ponuda posebnih događaja koji će omogućiti socijalizaciju mladih (koktel-party s tematikom muzeja, festivali glazbe i filma), 4) bolje fizičko okruženje muzeja (modernije uređenje, lagana i tiha glazba, postavljanje pozadina za fotografiranje mladih, 5) korištenje suvremene tehnologije (virtualne stvarnosti i ostalih tehnologija koji mogu priču o muzeju), 6) vodiče koji će se znati prilagoditi mladima (na zabavan način) te 7) posebne ponuda za mlade (popusta i posebnih cijena za studente).

\section{DISKUSIJA}

Istraživanje je pokazalo kako studenti imaju pretežito pozitivne asocijacije o muzejima iako ih više od polovine rijetko posjećuje (jednom u nekoliko godina). Stoga istraživanje potvrđuje dio rezultata do kojih su došli Drotner i sur. (2017) istražujući mlade u Danskoj, a odnosi se na podijeljene percepcije mladih o muzejima. Najveća negativna asocijacija studenata na muzeje u djetinjstvu jest „dosada“ čime se potvrđuju rezultati prijašnjih istraživanja (Drotner i sur., 2017; Hughes i Moscardo, 2019), odnosno asocijacija da su muzeji „mračni““.

Pozitivne asocijacije djelomično se razlikuju od prijašnjih istraživanja. U ovom istraživanju najznačajnija je pozitivna asocijacija ispitanika „zanimljivost“" muzeja, dok su ostale ,poučnost“ $i$,informativno“ (manje naglašene kod ispitanika). U usporedbi s rezultatima Drotnera i sur. (2017.) gdje je kod pozitivnih asocijacija naglašena iskustvena dimenzija posjeta muzeju (opuštanje, zabavu i uzbudljivost), u ovom istraživanju zabava nije česta asocijacija na posjet muzeju. Dio razloga dobivanja ovakvih rezultata leži i u činjenici da su muzeji u Republici Hrvatskoj dugo vremena bili usredotočeni na čuvanje baštine, a s vremenom su počeli nuditi različite usluge prilagođene posjetiteljima (Komarac, Ozretić Došen i Škare, 2017.).

U pogledu otkrivenih asocijacija na osobe koje posjećuju muzeje, otkrivene su izrazito pozitivne (znatiželjna, obrazovana, zainteresirana, pametna), uz jako nizak udio negativnih asocijacija (staromodna osoba). Dobiveni su rezultati slični onima (Hughes i Moscardo, 2019) koji su otkrili kako su glavne pozitivne asocijacije (intelektualac, zainteresirana, znatiželjna, smirena i bogata osoba) te negativne (starija osoba). Ovdje se postavlja pitanje koji su glavni razlozi zašto mladi izbjegavaju muzeje. 
Dio razloga leži u činjenici da muzeji nisu percipirani kao mjesta za socijalizaciju i druženje s prijateljima, što su pokazali i rezultati ovoga istraživanja, a upravo to danas mladi od muzeja očekuju (Hughes i Moscardo, 2019). Stoga muzeji trebaju nuditi više specijalnih događanja kako bi privukli mlade i publiku koja ih uobičajeno izbjegava. Događaji poput Noći muzeja, Ljetne noći, Festivali svjetla i slični događaji koji nude mogućnosti socijalizacije i druženja s prijateljima, dobar su način privlačenja mladih u muzeje jer oni najviše posjećuju takve događaje (Komarac, Ozretić Došen i Jurić Bulatović, 2019).

U pogledu uloge muzeja u društvu, ispitanici smatraju muzeje pozitivnim akterima društva jer nude edukaciju o određenim temama, vremenima, događajima i osobama, čime se djelomično potvrđuju prijašnje istraživanje Hughesa i Moscardoa (2019). Dodatno, muzeji bi trebali poticati na razmišljanje, zabavu i uživanje, što djelomično potvrđuje Drotner i sur., (2017) o muzejima kao mjestima zabave i uzbudljivih iskustava. Istovremeno edukacija, zabava i uživanje te promišljanje o određenim temama dio su prihvaćene misije muzeja krovne organizacije muzeja diljem svijeta International Council of Museum (2019) još od 1961. godine. Stoga ne iznenađuje činjenica da ispitanici upravo tako i vide ulogu muzeja u društvu.

Dodatno, muzeji su posebni po tome što nude specifična znanja i informacije te autentične predmete. Autentičnost je važna za muzeje (Hede i Thyne, 2010), bez obzira radili se o autentičnim predmetima koji muzeju izlažu ili autentičnim replikama (Varutti, 2018). Oni danas nastoje pružiti autentična iskustva posjeta muzeju, koja nisu isključivo vezana samo za autentične predmete već cjelokupno autentično iskustvo koje obuhvaća i ostvarivanje vlastite autentičnosti u muzeju (Hede, Garma, Jossiasen i Thyne, 2014; Komarac, Ozretić Došen i Škare, 2020).

Prijedlozi ispitanika o sedam područja poboljšanja usluge muzeja zapravo upućuju na glavne nedostatke zbog kojih je dio mladih nezainteresiran za posjet. Oni se mogu sumirati u nedostatak interakcije u muzeju (s osobljem muzeja i s predmetima u muzeju, te drugim korisnicima poput prijatelja), nedostatak programa prilagođenih mladima, komunikacije i cijene koja se prilagođava mladima te nedostatak suvremenijih tehnologija u muzejima). Do istih su rezultata došli i Hughes i Moscardo (2019.) što navodi na zaključak da se s istim problemima i izazovima susreću i muzeji u drugim zemljama. Dio rješenja problema s kojim se susreću muzeji (poput smanjenog interesa za muzeje među mladima, te smanjenim prihodima) leži u promjeni orijentacije sa skrbničke uloge (engl. custodial) na posjetitelje (engl. visitor orientation). Takva orijentacija uz pomoć tehnoloških inovacija prema istraživanju Camareroa, Garridoa i Vicentea (2015) ima pozitivan utjecaj na prihode i ekonomičnost muzeja. 


\section{OGRANIČENJA I PREPORUKE ZA BUDUĆA ISTRAŽIVANJA}

Ograničenja provedenog istraživanja odnose se na vrstu i veličinu uzorka, namjerni prigodni uzorak od 110 ispitanika, studenata Ekonomskog fakulteta u Zagrebu. Isto tako, ispitivane i percepcije muzeja mladih iz Republike Hrvatske čije su percepcije oblikovane pretežno iskustvima posjete hrvatskim muzejima, a manjim dijelom posjetima muzejima izvan Republike Hrvatske. Ispitivana je i opća percepcija o muzejima, koja se može razlikovati od muzeja do muzeja. Stoga se rezultati dobiveni ovim istraživanjem ne mogu generalizirati na sve studente svih fakulteta u Republici Hrvatskoj ni na za sve muzeje, no oni su indikativni i upućuju na daljnju potrebu istraživanja ovoga područja. Navedena ograničenja treba imati na umu pri interpretaciji rezultata i donošenju zaključaka. Usprkos navedenim ograničenjima, dobiveni rezultati istraživanja polazna su točka za daljnja istraživanja kako mladi u Republici Hrvatskoj percipiraju muzeje.

U budućim istraživanjima percepcija mladih trebalo bi obuhvatiti studente različitih fakulteta iz različitih gradova u Republici Hrvatskoj kako bi se dobio širi uvid u to kako studenti percipiraju muzeje. Isto bi tako u budućim istraživanjima trebalo istražiti percepcije studenata o virtualnim muzejima koji koriste interaktivne tehnologije u prezentaciji ponude muzeja.

\section{ZAKLJUČAK}

Studenti u Republici Hrvatskoj već se u najranijoj životnoj dobi susreću s muzejima, najčešće kao dio školskog programa. Istraživanje je otkrilo pozitivnu percepciju koja je vezana uz pozitivnu percepciju posjeta muzejima u djetinjstvu, ali i kasnija iskustva posjeta muzejima. Nadalje, negativna ili neutralna iskustva najčešće su rezultat nezainteresiranosti za muzeje u djetinjstvu ili loša iskustva u određenim muzejima (sumorne i hladne atmosfere).

Istraživanje je pokazalo i da dio studenata redovito posjećuje muzeje i zainteresirani su za posjete, no dio njih veoma ih rijetko ili uopće ne posjećuje jer su nezainteresirani. Općenita zainteresiranost studenata za posjete muzejima dok su putovanju u ulozi turista veća je nego u mjestu prebivališta. To upućuje na mogućnost povećanja interesa studenata u mjestima prebivališta ako muzeji odluče poraditi na nedostacima i pružiti usluge namijenjene mladima.

Studenti percipiraju muzeje kao mjesta u kojima se mladi osjećaju ugodno i dobrodošlo, koja pružaju provjerene informacije, kojima vjeruju te mogu pronaći odgovore na određena pitanja što je iznimno važno za muzeje. Muzeji trebaju 
T. KOMARAC, S. BEŠLIĆ: Uvid u percepciju muzeja i mogućnosti poboljšanja usluge muzeja: perspektiva studenata EKONOMSKI PREGLED, 72 (3) 358-376 (2021)

iskoristiti tu činjenicu pri izgradnji odnosa sa studentima kroz daljnji jasan i transparentan rad u zajednici.

Studenti žele interaktivniji odnos s muzejom i u muzeju, što je dio muzeja u Republici Hrvatskoj već dobro prepoznao. Za to je potrebna volja i znanje menadžmenta muzeja te ulaganje dodatnih resursa koji su ograničeni (od ljudskih resursa, financijskih pa sve do prostornih resursa). Europski muzeji koji su promijenili svoju orijentaciju prema posjetiteljima ostvaruju veće prihode. Hrvatski muzeji tek počinju mijenjati svoje orijentacije od skrbničke prema posjetiteljima, što bi im omogućilo veće prihod, a time i manju ovisnost o državnom ili gradskom proračunu iz kojega se financiraju.

Provedeno istraživanje upućuje na to studenti u Republici Hrvatskoj, s obzirom na pozitivnu percepciju muzeja i njihove uloge u društvu kao i osoba koje posjećuju muzeje, predstavljaju segment potrošača na koji bi se muzeji trebali fokusirati. Vidljiv je interes studenata za ponudu i vrijednosti koje muzeji predstavljaju, no sada je na menadžmentu muzeja da prepozna taj segment i uloži dodatne napore u njihovo privlačenje i zadržavanje u muzeju.

Dodatna znanstvena istraživanja percepcija studenata (i općenito mladih) u Republici Hrvatskoj prijeko su potrebna i trebaju biti usmjerena boljem razumijevanju studenata kao potencijalno važnoga segmenta korisnika muzeja.

\section{POPIS LITERATURE}

1. Assael, H. (2004). Consumer Behaviour: A Strategic Approach. New York: Houghton Mifflin Company.

2. Barron, P. i Leask, A. (2017). Visitor engagement at museums: Generation Y and 'Lates' events at the National Museum of Scotland. Museum Management and Curatorship, 32(5), 473-490. DOI: 10.1080/09647775.2017.1367259

3. Caldwell, N. i Coshall, J. (2002). Measuring brand associations for museums and galleries using repertory grid analysis. Management Decision, 40(4), 383392. DOI: 10.1108/00251740210426376

4. Camarero, C., Garrido, M.J. i Vicente, E. (2015). Achieving effective visitor orientation in European museum. Innovation versus custodial. Journal of Cultural Heritage, 16(2), 228-235. DOI: 10.1016/j.culher.2014.05.006

5. Colbert, F. (2014). The arts sector: A marketing definition. Psychology \& Marketing, 31(8), 563-565. DOI: 10.1002/mar.20717

6. Creswell, J.W. (2009). Research design: qualitative, quantitative, and mixed methods approaches. Thousand Oaks: Sage. 
7. d'Astous, A., Giraud Voss,Z., Colbert, F., Carù,A.,Caldwell, M.i Courvoisier,F. (2008). Product-country images in the arts: a multi-country study. International Marketing Review, 25(4), 379-403. DOI: 10.1108/02651330810887459

8. Drotner, K., Vestergaard Knudsen, L. i Hviid-Mortenesen, C. (2017). Young people's own museum views. Museum Management and Curatorship, 32(5), 456-472. DOI: 10.1080/09647775.2017.1368032

9. European Commission (2017). Special Barometer Report. https:ec.europa.eu/commfrontoffice/publicopinion/index.cfm/ResultDoc/download/ DocumentKy/80882 (29.12.2019.)

10. Farrell, B. i Medvedeva, M. (2010). Demographic Transformation and the Future of Museums. https://www.aam-us.org/wp-content/uploads/2017/12/ Demographic-Change-and-the-Future-of-Museums.pdf (12.6.2019.)

11. Gofman, A., Moskowitz, H.R. i Mets, T. (2011). Marketing museums and exhibitions: What drives the interest of young people?. Journal of Hospitality Marketing \& Management, 20(6), 601-618. DOI:10.1080/19368623.2011.5776 96

12. Hanquinet, L. i Savage, M. (2012). Educative leisure and the art museum. Museum \& Society, 10(1), 42-59. Dostupno na http://eprints.lse.ac.uk/49660/

13. Hede, A., Garma, R., Josiassen, A. i Thyne, M. (2014). Perceived authenticity of the visitor experience in museums: Conceptualization and initial empirical findings. European Journal of Marketing, 48(7/8), 1395-1412. DOI : 10.1108/ EJM-12-2011-0771

14. Hede, A.M., i Thyne, M. (2010). A journey to the authentic: Museum visitors and their negotiation of the inauthentic. Journal of Marketing Management, 26(7-8), 686-705. DOI: 10.1080/02672571003780106

15. Hughes, K. i Moscardo, G. (2017). Connecting with New Audiences: Exploring the Impact of Mobile Communication Devices on the Experiences of Young Adults in Museums. Visitor Studies, 20(1), 33-55, DOI: 10.1080/10645578.2017.1297128

16. Hughes, K. i Moscardo, G. (2019). For Me or Not for Me? Exploring Young Adults' Museum Representations. Leisure Sciences, 41(6), 516-534. DOI: 10.1080/01490400.2018.1550455

17. International Council of Museums [ICOM] (2019). ICOM Archives. http://archives.icom.museum/hist_def_eng.html, (28.12.2019.)

18. Kesić, T. (2006). Integrirana marketinška komunikacija, Zagreb: Opinio.

19. Kinsley, R.P. (2016). Inclusion in museums: a matter of social justice. Museum Management and Curatorship, 31(5), 474-490. DOI: 10.1080/09647775.2016.1211960 
T. KOMARAC, S. BEŠLIĆ: Uvid u percepciju muzeja i mogućnosti poboljšanja usluge muzeja: perspektiva studenata EKONOMSKI PREGLED, 72 (3) 358-376 (2021)

20. Komarac, T., Ozretić Došen, Đ. i Jurić Bulatović, V. (2019). The role of special event in attracting museum visitors and popularizing museums. Tourism in Southern and Eastern Europe 2019 - Conference Proceedings, 5, 375-387. DOI: $10.20867 /$ tosee. 05.38

21. Komarac, T., Ozretić Došen, Đ. i Škare, V. (2017). Understanding competition and museum offer in museum marketing. Academia Revista Latinoamericana de Administración, 30(2), 215-230. DOI: 10.1108/ARLA-07-2015-0159

22. Komarac, T., Ozretić Došen, Đ., i Škare, V. (2020). Managing edutainment and perceived authenticity of museum visitor experience: Insight from qualitative study. Museum Management and Curatorship, 3(2). DOI: 10.1080/09647775.2019.1630850

23. Kotler, P. i Keller, K.L. (2008). Upravljanje marketingom. Zagreb: Mate

24. Manchaiah, V. Zhao, F., Wildén, S., Auzenne, J., Beukes, E. W., Tomé, D., Mahadeva, D., Krishna, R., i Germundsson, P. (2017). Social representation of "music" in young adults: A cross-cultural study. International Journal of Audiology, 56(1), 24-32. DOI: 10.1080/14992027.2016.1227481

25. Mason, D.D.M. i McCarthy, C. (2006). 'The feeling of exclusion': Young peoples' perceptions of art galleries. Museum Management and Curatorship, 21(1), 20-31. DOI: 10.1080/09647770600402101

26. Museum as Toolbox (2019). Museum as Toolbox,www.museumastoolbox.eu/ home/museum-as-toolbox/, (19.6.2019.)

27. Museum of London, (2019). http://www.museumoflondon.org.uk, (19.6.2019.)

28. Rentfrow,P.J.,McDonald,J.A.i Oldmeadow,J. A. (2009). You are what you listen to: Young people's stereotypes about music fans. Group Processes \& Intergroup Relations, 12(3), 329-344. DOI: https://doi.org/10.1177/1368430209102845

29. Salgado, M. (2009). Openness, inclusion and participation in museums. Open Symposium, 1, 1-4. Dostupno na: www.keroul.qc.ca/DATA/ PRATIQUEDOCUMENT/252_en.pdf

30. Sheng, C.W. i Chen, M.C. (2012). A study of experience expectations of museum visitors. Tourism Management, 33(1), 53-60. DOI: 10.1016/j.tourman.2011.01.023

31. Tashakkori,A.i Creswell,J.W.(2007).Editorial: The new era of mixed methods. Journal of Mixed Method Research, 1(1), 3-7. DOI: 10.1177/2345678906293042

32. Thyne, M. (2001). The importance of values research for nonprofit organisations: The motivation-based values of museum visitors. The International Journal of Nonprofit and Voluntary Sector Marketing, 6(2), 116-130. DOI: $10.1002 /$ nvsm. 140 
33. Tzibazi, V. (2013). Participatory Action Research with young people in museums. Museum Management and Curatorship, 28(2), 153-171. DOI: 10.1080/09647775.2013.776800

34. Varutti, M. (2018). Authentic reproductions: Museum collection practices as authentication. Museum Management and Curatorship, 31(1), 42-56. DOI: 10.1080/09647775.2017.1387589

\section{INSIGHT INTO THE PERCEPTIONS OF MUSEUMS AND OPPORTUNITIES FOR MUSEUM SERVICE IMPROVEMENT: A STUDENT PERSPECTIVE}

Summary

The aim of this paper is to explore students' perceptions of museums in the Republic of Croatia. Because of a lack of research of this topic, we tried specifically to: (1) find out how students describe museums and museum visitors, (2) discover the role of museums in society and (3) collect students' suggestions on how museums can improve the museum visitor experience. A mixed-method research methodology that combines qualitative and quantitative data was used. A questionnaire with open-ended and closed questions was administered as a research instrument to obtain insight into the perceptions of museums. The research was conducted on a sample of 110 respondents (students). We found that students have a positive perception of museums and museum visitors. The role of museums in society is related to education and cultural uplift, while the uniqueness museums compared to other institutions arises from the fact that they offer specific knowledge and skills and display authentic objects. Students' suggestions for improvements in museum experience are related to the interactivity and customisation of museum services. Research limitations are related to the sample size and structure, an intentional sample of 110 respondents (students) of a single faculty in Zagreb. This is the first paper to provide an insight into students' museum perceptions in the Republic of Croatia using a mixed-method research methodology.

Keywords: students' perception, museums, the Republic of Croatia, mixed-method methodology 